\title{
ANALISIS PENERAPAN AKUNTANSI PERTANGGUNGJAWABAN DENGAN EFEKTIVITAS PENGENDALIAN BIAYA PADA HOTEL AWANA DI KOTA PALOPO
}

\author{
Risal*1Sri Wahyuni $^{2}$ \\ ${ }^{1}$ Sekolah Tinggi Ilmu Ekonomi Muhammadiyah Palopo \\ ${ }^{*}$ risal@stiem.ac.id
}

\begin{abstract}
This study aims to analyze and determine the role of accountability accounting in supporting the effectiveness of cost control at Awana Hotels in Palopo City. Methods of data collection are carried out from literature studies by reading the literature on accountability accounting systems and field studies originating from observing and retrieving data by conducting interviews conducted by asking questions directly by the interviewer to the respondent, then respondent's answers are recorded / recorded. The results of the study show that the application of accountability accounting has little role in supporting the effectiveness of cost control at Awana Hotels in Palopo City. The conclusion of this study is that Hotel Awana in Palopo City has applied the concept of accountability accounting even though its implementation is not perfect due to the absence of budgeting, uncontrolled and uncontrolled segregation of funds and the absence of account code classification at Awana Hotels in Palopo City, so It is recommended to make budgeting, do controlled separation of costs and uncontrolled costs and better record transactions using account codes.
\end{abstract}

Keywords: Application Accountancy Accounting, Cost Effectiveness Effectiveness.

\begin{abstract}
Abstrak : Penelitian ini bertujuan untuk menganalisis dan mengetahui peran akuntansi pertanggungjawaban dalam menunjang efektifitas pengendalian biaya pada Hotel Awana di Kota Palopo. Metode pengumpulan data dilakukan dari studi pustaka dengan cara membaca literatur-literatur tentang sistem akuntansi pertanggungjawaban dan studi lapangan yang berasal dari pengamatan dan pengambilan data dengan melakukan cara Wawancara yang dilakukan dengan mengajukan pertanyaan langsung oleh pewawancara kepada responden, kemudian jawaban-jawaban responden dicatat/direkam. Hasil penelitian yang menunjukkan bahwa bahwa penerapan akuntasi pertanggungjawaban kurang berperan dalam menunjang efektivitas pengendalian biaya pada Hotel Awana di Kota Palopo. Kesimpulan dalam penelitian ini adalah bahwa Hotel Awana di Kota Palopo telah menerapkan konsep akuntansi pertanggungjawaban meskipun penerapannya belum sempurna yang disebabkan oleh tidak adanya penyusunan anggaran, tidak melakukan pemisahan biaya terkendali dan tidak terkendali serta tidak adanya klasifikasi kode rekening pada Hotel Awana di Kota Palopo, sehingga disarankan untuk melakukan penyusunan anggaran, melakukan pemisahan biaya terkendali dan biaya tidak terkendali dan sebaiknya melakukan pencatatan transaksi dengan menggunakan kode rekening.
\end{abstract}

Kata kunci: Penerapan Akuntansi Pertanggungjawaban, Efektivitas Pengendalian Biaya.

\section{PENDAHULUAN}

Melihat luas dan kompleksnya kegiatan operasi hotel tidak memungkinkan bagi pimpinan untuk memantau secara langsung seluruh kegiatan hotel. Untuk itu pimpinan harus mengadakan pendelegasian wewenang dan tanggungjawab yang sangat penting ke tingkat pimpinan dibawahnya (para pelaksana) dalam pengambilan keputusan sehingga semua masalah yang ada dapat ditangani lebih baik dan cermat.

Dengan adanya pendelegasian tugas dan wewenang akan timbul berbagai tingkat tanggungjawab dan wewenang dalam organisasi, oleh karenanya perlu menerapkan akuntansi pertanggungjawaban yang merupakan suatu sistem untuk mengendalikan

tanggungjawab tiap unit kerja atau departemen yang lebih dikenal pusat pertanggungjawaban. Pengendalian yang dijalankan manajemen ini merupakan bagian dari sistem pengendalian manajemen yang dikembangkan untuk membantu manajemen dalam mengendalikan kegiatan operasi perusahaan.

Pelaksanaan pengendalian yang dilakukan melalui penerapan akuntansi 
pertanggungjawaban adalah dengan cara mengelompokkan tanggung jawab dan menggariskan secara jelas hubungan satu bagian dengan bagian lainnya dalam perusahaan, disertai dengan pertanggungjawaban dari masing-masing tingkatan secara terinci.

Bertitik tolak dari uraian di atas dapat ditarik kesimpulan bahwa akuntansi pertanggungjawaban pada perusahaan, khususnya Perusahaan Jasa yaitu Hotel adalah sangat penting, untuk mengendalikan tanggungjawab tiap departemen. Berdasarkan hal tersebut, maka penulis memilih judul "Analisis Penerapan Akuntansi Pertanggungjawaban dengan efektivitas Pengendalian Biaya Pada Hotel Awana di Kota Palopo. Tujuan dari penelitian ini adalah: Untuk menganalisis dan mengetahui penerapan akuntansi pertanggungjawaban berperan dalam menunjang efektivitas pengendalian biaya pada Hotel Awana di Kota Palopo.

\section{KAJIAN PUSTAKA}

\section{Akuntansi Pertanggungjawaban}

Akuntansi pertanggungjawaban adalah Sistem yang mengukur berbagai hasil yang dicapai oleh setiap pusat pertanggungjawaban menurut informasi yang dibutuhkan oleh para manajer untuk mengoperasikan pusat pertanggungjawaban mereka (Hansen \& Mowen 2005:116).

\section{Pengendalian Biaya}

Pengendalian Biaya adalah langkah yang diambil oleh manajemen untuk memastikan bahwa tujuan biaya yang dibuat pada tahap perencanaan dapat dicapai, dan untuk memastikan bahwa semua segmen fungsi organisasi dalam perilakunya konsistensi dengan kebijakan-kebijakan untuk pengawasan biaya yang efektif (siegel dkk, 1999:110).

\section{Hubungan Akuntansi Pertanggung jawaban dengan Pengendalian Biaya}

Dalam hal ini akuntansi pertanggungjawaban merupakan alat yang dipakai untuk mengendalikan biaya, karena dalam akuntansi pertanggungjawaban biaya-biaya dilaporkan menurut pusat pertanggungjawaban tertentu. Pengendalian dapat dilakukan dengan cara memberikan peran bagi setiap manajer untuk merencanakan pendapatan dan biaya tersebut menurut manajer yang bertanggung jawab Mulyadi (2003:385).

\section{METODE}

Untuk lebih menfokuskan kegiatan penelitian dalam memperoleh data yang dibutuhkan dalam penelitian nantinya, maka penulis memilih lokasi dan objek yaitu pada Hotel Awana di Kota Palopo.Sedangkan waktu yang dipergunakan dalam penelitian diperkirakan kurang lebih 2 (dua) bulan.

\section{Jenis dan Sumber Data}

Adapun jenis data yang digunakan: a)Data kualitatif, yaitu data yang diperoleh dari hasil wawancara dengan pimpinan perusahaan dan karyawan dalam perusahaan serta informasi-informasi yang diperoleh dari pihak lain yang berkaitan dengan masalah yang diteliti.

a. Data Kuantitatif adalah data yang diperoleh dalam bentuk angka-angka yang dapat dihitung. Sumber data, terdiridari: 1)Data Primer yaitu Data primer diperoleh dari hasil wawancara langsung dari pihak Hotel Awana di Kota Palopo atau bagian yang berwewenang meliputi penjelasan akuntansi pertanggungjawaban merupakan data yang belum jadi kemudian diolah. 2) Data Sekunder, data yang diperoleh dari perusahaan sebagai objek penelitian yang sudah diolah dan terdokumentasi

di perusahaan,misalnyasejarahsingkatpe rusahaan, strukturorganisasi, danbukti atau catatan yang 
berhubungan dengan proses akuntansi pertanggungjawaban.

\section{Metode Pengumpulan Data}

Proses pengumpulan data yang diperlukan. Pn dengan studi kepustakaan dengan cara membaca literatur-literatur tentang sistem akuntansi pertanggungjawaban. Dan langsung pada Hotel Awana Kota Palopo. Data yang didapat dari lapangan berasal dari pengamatan dan pengambilan data dengan melakukan cara Wawancara.

\section{Metode Analisis Data}

Metodeanalisis yang digunakan, adalahAnalisis kuantitatif digunakan dalam bentuk angka-angka yang kemudian dijelaskan dan diiterpretasikan dalam suatu uraian dan diproses dengan cara setiap variabel diberikan nilai berdasarkan jumlah jawaban "YA" yang terdapat dalam kuisioner.

Untuk menghitung persentase tersebut digunakan rumus (Champion, 1990:34):

Jumlah jawaban YA

Persentase $=$ $100 \%$

Jumlah jawaban seluruh responden

Penilaian hasil persentase diklasifikasikan menurut ketentuan yang dikemkakan oleh Champion (1990:34) yaitu: a. $0 \%$ - 25\%, berarti akuntansi pertanggungjawaban tidak berperan dalam menunjang efektivitas pengendalian biaya.

b. $26 \% \quad-\quad 50 \%$,berarti akuntansi pertanggungjawaban kurang berperan dalam menunjang efektivitas pengendalian biaya.

c. $51 \%$ - $75 \%$,berarti akuntansi pertanggungjawaban cukup berperan dalam menunjang efektivitas pengendalian biaya.

d. $76 \%$ - 100, berarti akuntansi pertanggungjawaban sangat berperan dalam menunjang efektivitas pengendalian biaya.

\section{HASIL DAN PEMBAHASAN}

\section{Analisis Kuantitatif}

Analisis kuantitatif ditujukan untuk menguji hipotesis ada tidakanya peranan penerapan akuntansi pertanggungjawaban dalam menunjang efektifivitas pengendalian biaya pada Hotel Awana di Kota Palopo.

Untuk mendapatkan data, penulis menyebarkan kuisioner yang berisi pertanyaan-pertanyaan yang berhubungan dengan masalah yang dibahas. Kuisioner tersebut disebarkan pada 5 orang yang dianggap relevan dengan masalah yang diteliti.

Berdasarkan hasil pengumpulan jawaban dari 5 orang responden, maka dapat diperoleh nilai yang merupakan hasil dari kusioner sebagai berikut:

a. Jawaban kuisioner penerapan akuntansi pertanggungjawaban

$\begin{array}{ll}\text { Jawaban YA } & =40 \\ \text { Jawaban TIDAK } & =60+ \\ \text { Total } & =100\end{array}$

Selanjutnya dihitung dengan menggunakan rumus dan didapat hasil perhitungan kuisioner penerapan akuntansi pertanggungjawaban sebagai berikut:

$$
\text { Persentase }=\stackrel{\text { Jumlah jawaban YA }}{\longrightarrow} \mathrm{X}
$$

$100 \%$

$$
\begin{aligned}
& \text { Jumlah jawaban seluruh } \\
& \text { responden }
\end{aligned}
$$

$$
=\frac{40}{100} \times 100 \%=\mathbf{4 0} \%
$$

Dari perhitungan diatas, diperoleh hasil40\%.Berdasarkan kriteria-kriteria yang ditentukan, maka nilai tersebut 
termasuk ke dalam range $26 \%$ - 50\% dan dapat disimpulkan bahwa akuntasi pertanggungjawaban yang diterapkan kurang berperan.

$\begin{array}{ll}\text { b. Jawaban kuisioner } & \text { efektivitas } \\ \begin{array}{ll}\text { pengendalian biaya } & \\ \text { Jawaban YA } & =30 \\ \text { Jawaban TIDAK } & =10+ \\ \text { Total } & =40\end{array}\end{array}$

Selanjutnya dihitung dengan menggunakan rumus dan didapat hasil perhitungan kuisioner efektivitas pengendalian biaya sebagai berikut: Jumlah jawaban YA



Jumlah jawaban seluruh responden

$$
=\frac{30}{40} \times 100 \%=75 \%
$$

Dari perhitungan diatas, diperolehhasil75\%. Berdasarkan kriteriakriteria yang ditentukan, maka nilai tersebut termasuk ke dalam range 51\% - 75\% dan dapat disimpulkan bahwa pengendalian biaya yang diterapkan cukup berperan/efektif.

Untuk mengetahui penerapan akuntansi pertanggungjawaban berperan dalam menunjang efektivitas pengendalian biaya pada Hotel Awana di Kota Palopo, maka dilakukan dengan cara menggabungkan/menjumlahkan hasil kuisioner penerapan akuntansi pertanggungjawaban dan efektivitas pengendalian biaya secara keseluruhan sebagai berikut:

$\begin{array}{ll}\text { Jawaban YA } & =70 \\ \text { Jawaban TIDAK } & =70+ \\ \text { Total } & =140\end{array}$

Selanjutnya dihitung dengan menggunakan rumus dan didapat hasil perhitungan kuisioner penerapan akuntansi pertanggungjawaban sebagai berikut:
Jumlah jawaban YA



Dari perhitungan diatas, diperoleh hasil50\%. Berdasarkan kriteria-kriteriayang ditentukan, maka nilai tersebut termasuk ke dalam range $26 \% \quad-50 \%$ dan dapat disimpulkan bahwa penerapan akuntasi pertanggungjawaban kurang berperan dalam menunjang efektivitas pengendalian biaya pada Hotel Awana di Kota Palopo. Hal ini berarti hipotesis ditolak (tidak terbukti).

Hasil penelitian ini tidak sesuai dengan teori yang dikemukakan oleh Mulyadi (2003:385) menyatakan bahwa Informasi akuntansi pertanggungjawaban merupakan informasi yang penting dalam proses perencanaan dan pengendalian aktivitas organisasi, karena informasi ini menekankan hubungan antara informasi dengan manajer yang bertanggungjawab terhadap perencanaan dan realisasinya. Pengendalian dapat dilakukan dengan cara memberikan peran bagi setiap manajer untuk merencanakan pendapatan dan biaya tersebut menurut manajer yang bertanggungjawab.

\section{KESIMPULAN}

Berdasarkan hasil analisis dan pembahasan Hotel Awana di Kota Palopo telah menerapkan konsep akuntansi pertanggungjawaban, meskipun penerapannya belum sempurna, karena belum didukung oleh seluruh unsur yang menjadi syarat akuntansi pertanggungjawaban. Hal-hal yang kurang mendukung dalam penerapan akuntansi pertanggungjawaban pada Hotel Awana di Kota Palopo seperti, tidak adanya penyusunan anggaran, tidak melakukan 
pemisahan biaya terkendali dan tidak terkendali serta tidak adanya klasifikasi kode rekening. Penerapan akuntasi pertanggung jawaban kurang berperan dalam menunjang efektivitas pengendalian biaya pada Hotel Awana di Kota Palopo.

\section{DAFTAR PUSTAKA}

Anonim, Ikatan Akuntan Indonesia. 1994. Standar Akuntansi Keuangan. Jakarta: Salemba Empat.

Champion, Dean. 1990. Basic Statistic For Social Research, MC Millan Publishing Co. Inc. New York.

David Doyle. 2001. Pengendalian Biaya. Jakarta: PT. Pustaka Binaman Presindo.

Hansen \& Mowen. 2005.Management Accounting, Buku 2, Edisi ke-7Jakarta: Salemba Empat.

Henry Simamora. 1999.Akuntansi Manajemen. Jakarta: Salemba Empat.

Hansen \& Mowen. 2005.Management Accounting, Edisi Ke-7, Jakrta: Salemba Empat.

L.M. Samryn. 2001.Akuntansi Manajerial Suatu Pengantar. Jakarta: Rajawali Pers.

Moriarty and Allen. 1991.Akuntansi Manajemen, Edisi Ke-4, Yogyakarta: BPFE.

Mulyadi. 2003.Akuntansi Manajemen, Edisi Ke-2, Yogyakarta: STIE YKPN.

Robert N.Anthony, Vijay Govindarajan. 2001. SPM Buku 1. Jakarta: Salemba Empat.
Garrison, Ray H. 2001. AkunansiManjemen, Buku 1, ITB, Bandung.

Siegel, Sidney.1999. Statistik Non Parametrik Untuk Ilmu Sosial.Jakarta: Gramedia.

Sugiyono.2001. Metode Penelitian Bisnis, Edisi Ke-4. Bandung: CV. Alfa Beta.

Supriyono. 2002. Anggaran Perusahaan, edisi ke-1. Yogyakarta: YKPN. 